Discourse and Communication for Sustainable Education, vol. 12, no. 1, pp. 121-139, 2021

\title{
From the "Greta Thunberg Effect" to Green Conversion of Universities: The Reconstructive Praxis of Discursive Mobilizations
}

\author{
Jonathan Michael Feldman \\ Stockholm University, Stockholm, Sweden
}

\begin{abstract}
This paper investigates how one could envision a discursive mobilization process to transform protest movements into agents that help reconstruct the universities as agents supporting material mobilizations leading to ecological reconstruction. After reviewing universities' ecological footprints, the author shows how theories of mobilization and conjunctures could contribute to understanding how this transformation could occur. Discursive mobilizations advance values or ideas but stop short of innovation and production system changes. Material mobilizations affect deployment of human, technological, industrial and financial resources. Conjunctures involve linkages of political activity to spaces implicated in both kinds of mobilizations in a given historical time frame. The study shows many nations having both extensive climate activism and concentrations of university students creating a possibility for greening education centers based on various models for doing so. Yet, two key problems emerge. First, some nations lag in climate activism. Second, interest in a Green Deal or Green New Deal does not always match the level of attention to leading activist Greta Thunberg. The paper illustrates how such problems can be addressed by university-based campaigns linking activist cohorts, mobilization supporting green conversion of higher education and solidaristic, mutual aid exchanges among regions.
\end{abstract}

Key words: conjunctures, discursive mobilization, Fridays for Future, Green Deal, material mobilization, strategic interventions, uneven development

\section{Introduction}

Universities can contribute to global warming in various ways. One can compare the sources of global warming with university equivalents. In 2017, $29.0 \%$ of greenhouse gases in the EU came from the energy sector, $25.5 \%$ from fuel consumption (exclusive of transport), $23.8 \%$ from transport, $10.0 \%$ from agriculture, $8.7 \%$ from industrial processes and product use, and $3.0 \%$ from waste (Eurostat, 2020). These major emission sources correspond to university infrastructure. Spaces where we can see ecological footprints of universities include: direct energy use, water, mobility, procurement, waste, food and infrastructure (Lambrechts \& Van Liedekerke, 2014, p. 403) as seen in Table 1. 


\section{Table 1}

University Spaces of Ecological Mobilization

\begin{tabular}{|c|c|}
\hline $\begin{array}{l}\text { Area of } \\
\text { environmental } \\
\text { intervention }\end{array}$ & Examples of potential problems for university communities \\
\hline Energy & $\begin{array}{l}\text { The electricity and water use at large university campuses "are similar to } \\
\text { those of medium-sized cities" (a); A } 2012 \text { study found that "in Europe, } \\
\text { buildings account for } 40 \% \text { of total energy use and } 36 \% \text { of total CO2 } \\
\text { emissions" (b). }\end{array}$ \\
\hline Water & $\begin{array}{l}\text { In } 2004 \text {, Yale University in the U.S. used } 6 \text { million gallons of water across } \\
\text { the campus (c). }\end{array}$ \\
\hline Mobility & $\begin{array}{l}\text { In New Zealand data published in } 2019 \text { shows that more than half of the } \\
\text { country's students use private vehicles to commute. In other words, "more } \\
\text { than } 500,000 \text { New Zealand students drive themselves or are driven by } \\
\text { somebody else to school every day" (d). }\end{array}$ \\
\hline Procurement & $\begin{array}{l}\text { "In the U.S., according to } 2004 \text { figures, K-12 schools rank first as the } \\
\text { nation's largest institutional purchaser. State colleges and universities are the } \\
\text { second-largest institutional purchasers in the U.S." (e) In } 2017 \text {, there were } \\
19.8 \text { million tertiary students in the EU-28, representing a vast number of } \\
\text { potential commuters and consumers of energy, food and transportation } \\
\text { services, and products like computers, books, and paper (f). }\end{array}$ \\
\hline Waste & $\begin{array}{l}\text { An estimate around } 2015 \text { found that in the U.S., "the average student } \\
\text { produces... } 640 \text { pounds of trash annually" (g). }\end{array}$ \\
\hline Food & $\begin{array}{l}\text { A Swedish trade association for restaurants at universities Högskolerestau- } \\
\text { ranger, reports that they have } 40 \text { affiliates in the country, and eight to ten } \\
\text { affiliates in Stockholm (h); In the top five German cities, revenue for } \\
\text { university catering was worth } 81.21 \text { million Euro in } 2018 \text { (i). }\end{array}$ \\
\hline Infrastructure & $\begin{array}{l}\text { A report on the University of Washington, Seattle campus found that it } \\
\text { spent } \$ 15 \text { million each year on electricity, "with } 35 \% \text { of total electricity } \\
\text { consumed by lighting." There were } 1,987 \text { luminaires on the campus, "not } \\
\text { including building-mounted light sources" (j). }\end{array}$ \\
\hline
\end{tabular}

Note: Each of these areas corresponds to arenas where green conversion solutions can be introduced.

Sources: (a) Bonnet et al., 2002, p. 13; (b) Zhao and Magoulès, 2012 as cited in Mohammadalizadehkorde and Weaver, 2018, p. 8); (c) Stafford, 2011, p. 337; (d) Theunissen, 2019; (e); Czarnezki, 2019, p. 84; (f) Eurostat, 2019; (g) Planet Aid, 2015; (h) Hultgren, 2020; (i) Statista, 2020; (j) UW Integrated Design Lab, 2017.

From the 1980s onwards, many universities have been focused on "implementing changes in campus planning, construction, management and operations" to transform themselves into “Green Universities” (Wang et al., 2013, p. 1). The Talloires Declaration, United Nations and European Commission also have supported these goals (European Commission, 2019; Jain et al., 2013; Mohammadalizadehkorde and Weaver, 2018). Universities have addressed the Sustainable Development Goals (Murillo-Vargas et al., 2021). Spanish educational leaders have introduced sustainability criteria "into university management at all levels, including purchasing decisions." This led to the "Declaration of Universities about Green Procurement” which committed universities to gradually develop "a Green Procurement Policy and including it in their product supply contracts 
by prioritising [such procurement] whenever possible" (Pacheco-Blanco \& Bastante-Ceca, 2016, p. 649). In the U.S., green procurement has been used to support a large solar energy station at Florida Gulf Coast University (AASHE, 2015, p. 27). The Illinois Local Food, Farms and Jobs Act "declares that $20 \%$ of all food and food products purchased by State agencies and State-owned facilities, including...public universities, shall, by 2020, be local farm or food products" (Czarnezki, 2019, p. 81). From 2006 to 2011, the Sustainable Endowments Institute showed significant progress on five key indicators of ecological change at North American universities using diverse criteria. These criteria shows that many universities became "greener." The data covers institutions of higher education with the largest endowments in Canada and the United States (Table 2).

\section{Table 2}

Percentage of Schools Having Key Ecological Programs: Selected Higher Education Institutions in the United States and Canada

\begin{tabular}{lcc}
\hline \multicolumn{1}{c}{ Program Area } & 2006 & 2011 \\
\hline Commitment to carbon emissions reduction & $23 \%$ & $64 \%$ \\
Campus farm or garden & $9 \%$ & $70 \%$ \\
Trayless dining & $0 \%$ & $75 \%$ \\
Green building policy & $22 \%$ & $79 \%$ \\
Sustainability committee & $40 \%$ & $95 \%$ \\
\hline
\end{tabular}

(Orlowski, 2012).

\section{The Ecological Mobilization Gap}

Despite progress, mobilization gaps to promote ecological outcomes exist in areas like procurement or creating green offices (Pacheco-Blanco \& Bastante-Ceca, 2016, p. 651). Two reasons explaining such gaps are worth noting. First, we can see the uneven distribution of institutional resources where "wealthier institutions are more likely to develop sustainable practices" (Stafford, 2011, p. 340, 347; Salite, et al., 2020). The resource gap can manifest itself in an insufficient supply of inexpensive, yet proximate (local) housing which leads students to commute (Morris, 2018). Some universities are wealthier than others and a "lack of financial resources" can be a barrier to sustainability projects (Kowarski, 2020; Velazquez et al., 2005).

A second factor is based on regional differences in infrastructure, resources or ideological commitments potentially related to ideas, groups and constituencies embedded in particular regions (Bender, 2002; Stafford, 2011, p. 339; Smith, 1994). Some universities are more mass transit friendly than others, with student car ownership or use significant among some universities (AASHE, 2015, p. 34; Friedman, 2016). Regional differences include views about whether human beings contribute to climate change (Egan \& Mullin, 2017). This problem can be summarized as uneven (regional political-economic) development where (a) some universities and associated regions may be more proactive to address climate change than others and (b) action from above, by university administrators or even faculty, may be insufficient without external political encouragement from below by students, social movements or allies in green entrepreneurs, relevant trade associations or even government agencies supporting green outcomes. 


\section{Mobilization and Conjunctures in Theory and Practice}

The key strategic goal is how to accelerate ecological mobilization in the fashion elaborated above given constraints of time (related to ecological tipping points) and space (based on uneven development where different regions are more or less responsive to ecological needs). A comprehensive ecological policy must have depth (related to the multifaceted areas of interventions outlined in Table 1), but also breadth (related to territorial coverage) to address the problem of uneven development.

In terms of time, speed is required for comprehensive action through mobilization: "climate mitigation must be an urgent, rapid and effective transition" and we now need plans "for possible future emergency climate mitigation responses." Scientists, academics, politicians, and activists have argued that "rapid climate mitigation needs economic restructuring of the scale and rapidity as seen in wartime" with war mobilization viewed "as a policy model for rapid response to climate change." The wartime mobilization model has certain strengths in terms of speed and depth of response but is associated with less democratic decision-making (Delina \& Diesendorf, 2013, p. 371). The war mobilization metaphor refers to a material mobilization.

Grassroots involvement from below could extend democratic accountability and provide support for material mobilizations. Grassroots mobilizations often take the form of rhetorical protest or political activity that is short of material mobilization, i.e., such movements often appear as discursive mobilizations. Yet, discursive mobilizations can lead to material mobilizations because culture can be "a resource for technological change." One reason is that "cultural resources are...central in processes of co-production of knowledge and social order" (Elzinga, 1998, p. 30). Universities can be a key to this conversion system because they are "nexuses of our public culture," i.e., "systems that link and connect social institutions: schools, libraries, museums, performing-arts organizations, hospitals, parks, news media, and the growing universe of information providers on the Internet" (Duderstadt, 2000 as cited in Feldman, 2001, p. 117).

The conversion of a discursive mobilization into a material mobilization influencing breadth has occurred during movements to divest university endowments and other financial resources. These are only deconstructive material mobilizations based on shifting finance (or divesting from) as opposed to constructing and diffusing green technologies. In the movement against apartheid in South Africa, university divestment was followed by "a growing number of state and local governments in the US" who "added their weight to the divestment campaign from the late 1970s onward." So "by 1993, 40 of the top 50 colleges and universities (ranked by size of endowment) had some sort of divestment policy, as did the governments and pension funds of more than 100 states, counties, cities, and US territories" (Voorhes, 1999, p. 129). Institutional diversification helped extend protest beyond the university to encompass the procurement or political leverage of the local state, corporations and financial managers and beyond the university as the protest site. Extension by regional diffusion helped protest move beyond a narrow group of protest locations to a broader group. The development of the on-campus "shantytown" helped move protest from more advanced/traditional university protest regions to more peripheral regions (Soule, 1997, p. 856). As of April 2021, institutional divestments from fossil fuels totaled \$14.56 trillion, involving 1,318 institutions about $15 \%$ of which were educational institutions, $34 \%$ faith-based organizations, and $24 \%$ pension fund or government divestments (350.org, 2021). 
Another extension system in terms of breadth (in terms of coverage) but extending to depth (or understanding) can be seen in the so-called "Greta Thunberg Effect." First, "celebrities and public figures played an essential role in amplifying the influence of the activist" (Jung et al., 2020). Second, "those who are more familiar with Greta Thunberg have higher intentions of taking collective actions to reduce global warming and that stronger collective efficacy beliefs mediate this relationship" (Sabherwal et al., 2021, p. 1).

The idea of using universities as a site for reconstructive material mobilization on behalf of socially useful goals can be found in discussions about converting universities from servicing military to civilian clients (Feldman, 1989) or a "post-university" which would function as a space responding to the needs of various civil rights, ecological, peace and other constituencies in its design, innovation, production, marketing and distribution functions. Such movements, when linked to innovation and production platforms supported by the state, can produce green products. This form of mobilization leads to socially useful technological and productive deployments (Feldman, 2001). University mobilizations can include entrepreneurship education which in turn "can trigger and support" a process where entrepreneurs can become engaged and support sustainability (Linder, 2018, p. 115).

Social movements can be viewed as reflecting conjunctures, the "copresence of, or interaction between, phenomena in concrete time and space" (Timasheff, 1959, p. 162). They are "historically specific clusters of political performances" (Tilly, pp. 1993-1994). The universities function as a conjunctural space linking: (a) discursive mobilization, (b) an organizational/spatial platform for potential material mobilization, as well as (c) a relevant political, and presently active constituency. Universities are the ultimate destination for many Fridays for Future (FFF) protestors inspired by Greta Thunberg. We can see the conjunctural aspects of this movement in Tables 3 and 4, through lists of countries having various levels of ecological commitments, engaged in different levels of divestment actions, with large numbers of tertiary students and heterogeneous participation in FFF strikes.

Figure 1 illustrates how the frequency of FFF strikes is highly correlated with the number of institutional divestments, but also illustrates the problem of uneven regional political-economic development - with Southern and Eastern European countries less likely to be involved in either activity. The correlation ratio between number of strike actions and number of divestments was .676 for the EU-27 (cf. Table 3). When adding the five countries in Table 4, this correlation was .716. In the EU-27, a country having a lower rank in Yale's national environmental rating was negatively correlated with number of strikes (-.420) and number of institutional divestments (-.507). The general pattern is that East European and Southern European countries have not only lower environmental rankings as seen in Table 3, but also have lower average GDP per capita. The average GDP per capita of the Southern and Eastern European states was only $\$ 20,630.2$ in 2019 (based on an average of all figures for these countries). In contrast, the three Nordic EU nations had a comparable figure of \$54,065.33 and the remaining eight Western European Northern nations had an average GDP per capita of \$53,522.7 (based on data of the World Bank, 2021).

In Figures 2 through 6, we see how the popularity of Google search queries related to "Greta Thunberg" usually surpass similar searches about a "Green New Deal" or 
"Green Deal" (core concepts useful for greening universities) in both "advanced" and "lagging" ecological regions. One way to address these gaps is to change the character of mobilization aimed at universities and related network actors so that they make deeper commitments to change. I now explain how such a process might unfold. Figure 2 shows how Google searches in Poland related to Thunberg far outpaced other searches related to the two core concepts over a recent one year period. Figure 3 shows the same pattern in Germany which has greater activism and is richer in resources. Figure 4 shows an even more dramatic difference in Sweden, Thunberg's home base, where the two core concepts are relatively flat in terms of searches. Figures 5 and 6 show how in Bulgaria and Romania, two states relatively low in green activism, the two concepts are more competitive in terms of relative number of searchers.

\section{A Five Phase Pedagogic Process for Ecological Reconstruction}

The pedagogic process for leveraging higher learning institutions as levers for ecological reconstruction are related to five relevant outcomes and phases: (a) raising awareness about desired ecological outcomes and facilitating engagement, (b) mapping universities' existing projects and capacities that relate to these outcomes in relation to various actors, (c) creating or deepening networks of these actors to design new or complement existing plans and building strategic interventions in support of these outcomes, (d) implementation of designs, and (e) reflective learning and feedback. This process can begin with discursive mobilizations and is consolidated and extended by material mobilizations.

\section{Table 3}

Environmental Performance, Tertiary Students, Divestment and School Strike Actions by EU-27 Countries

\begin{tabular}{lcccc}
\hline Country & $\begin{array}{c}\text { Ranking in Yale } \\
\text { Environmental } \\
\text { Performance } \\
\text { Index (2020) }\end{array}$ & $\begin{array}{c}\text { Number of } \\
\text { Tertiary } \\
\text { Students } \\
(2018)\end{array}$ & $\begin{array}{c}\text { Institutions } \\
\text { Participating } \\
\text { in Divestment } \\
\text { Actions (2021) }\end{array}$ & $\begin{array}{c}\text { Number of Fridays } \\
\text { for Future Strikes: } \\
\text { November 30, 2018 } \\
\text { to June 25, 2021 }\end{array}$ \\
\hline Austria & 6 & 430,200 & 4 & 618 \\
Belgium & 15 & 515,500 & 25 & 104 \\
Bulgaria & 41 & 236,300 & 0 & 21 \\
Croatia & 34 & 164,800 & 0 & 18 \\
Cyprus & 31 & 47,200 & 0 & 11 \\
Czechia & 20 & 329,000 & 1 & 54 \\
(Czech Republic) & 1 & 310,900 & 13 & 146 \\
Denmark & 30 & 45,800 & 1 & 42 \\
Estonia & 7 & 294,500 & 1 & 107 \\
Finland & 5 & $2,618,700$ & 59 & 751 \\
France & 10 & $3,127,900$ & 37 & 2,193 \\
Germany & 25 & 766,900 & 1 & 60 \\
Greece & & & & \\
\hline
\end{tabular}


Continuation of Table 3

\begin{tabular}{lcccc}
\hline Hungary & 33 & 283,400 & 0 & 58 \\
Ireland & 16 & 231,200 & 23 & 131 \\
Italy & 20 & $1,896,000$ & 36 & 1,027 \\
Latvia & 36 & 81,600 & 0 & 13 \\
Lithuania & 35 & 118,300 & 0 & 15 \\
Luxembourg & 2 & 7,000 & 1 & 6 \\
Malta & 23 & 15,200 & 1 & 19 \\
Netherlands & 11 & 889,500 & 12 & 88 \\
Poland & 37 & $1,429,900$ & 0 & 159 \\
Portugal & 27 & 356,400 & 2 & 94 \\
Romania & 32 & 538,900 & 0 & 72 \\
Slovakia & 26 & 144,400 & 0 & 28 \\
Slovenia & 18 & 76,500 & 0 & 32 \\
Spain & 14 & $2,051,800$ & 5 & 546 \\
Sweden & 8 & 431,065 & 22 & 1,362 \\
\hline
\end{tabular}

Legend: June 25, 2021 data based on projected estimates.

Sources: Environmental Performance Index, 2021; Eurostat, 2021a; Eurostat, 2021b; Fridays for Future, 2021; 350.org, 2021.

\section{Table 4}

Environmental Performance, Tertiary Students, Divestment and School Strike Actions by Selected Countries

\begin{tabular}{lcccc}
\hline Country & $\begin{array}{c}\text { Ranking in Yale } \\
\text { Environmental } \\
\text { Performance } \\
\text { Index }(2020)\end{array}$ & $\begin{array}{c}\text { Number of } \\
\text { Tertiary } \\
\text { Students } \\
(2018)\end{array}$ & $\begin{array}{c}\text { Institutions } \\
\text { Participating } \\
\text { in Divestment } \\
\text { Actions (2021) }\end{array}$ & $\begin{array}{c}\text { Number of Fridays } \\
\text { for Future Strikes: } \\
\text { November 30, 2018 } \\
\text { to June 25, 2021 }\end{array}$ \\
\hline Australia & 13 & $1,562,520$ & 207 & 491 \\
Canada & 20 & $1,356,000^{*}$ & 50 & 807 \\
Norway & 9 & 288,739 & 9 & 124 \\
United Kingdom & 4 & $2,467,086$ & 264 & 952 \\
United States & 24 & $19,650,000$ & 398 & 3,153 \\
\hline
\end{tabular}

Legend: *: 2019 based on based on 2016 Postsecondary Student Information System data. June 25, 2021 data based on projected estimates.

Sources: Environmental Performance Index, 2021; Eurostat, 2021a; Eurostat, 2021b; Fridays for Future, 2021; Statista, 2021; 350.org. 2021; Universities Australia, 2021; 350.org, 2021; Universities Canada, 2021. 


\section{Figure 1}

Fossil Fuel Divestment Actions up to April 2021 (X-axis) vs. Number of Fridays for Future Strikes, 2018 - November 30, 2018 to June 25, 2021 in EU-27 (Y-axis)

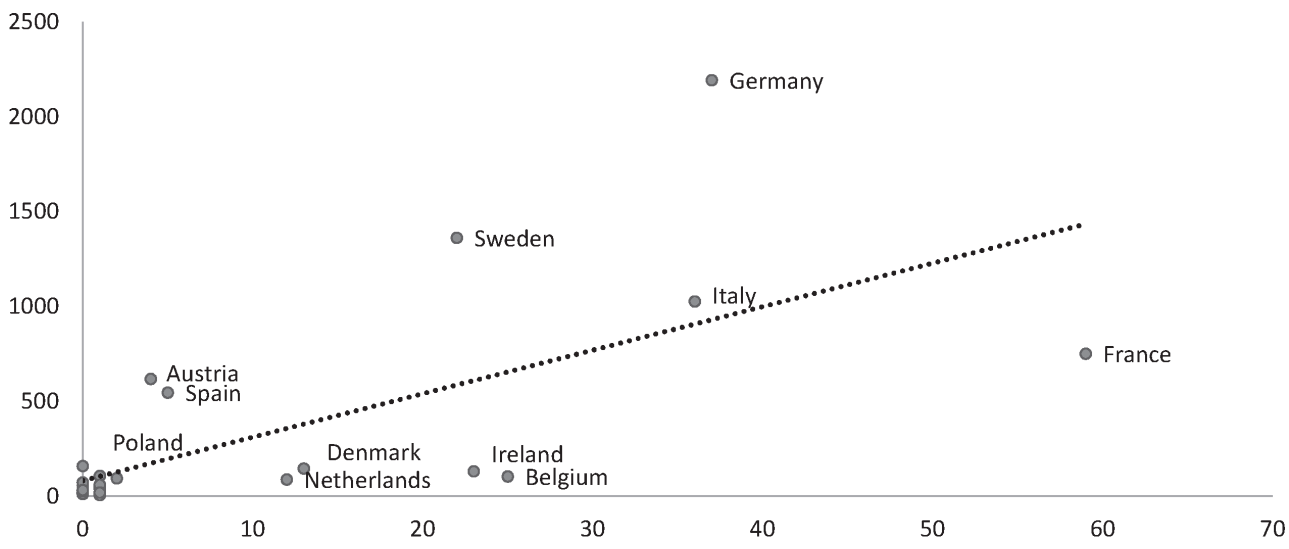

Legend: The number of fossil fuel divestment actions is based on the number of institutions in a given country engaged in some form of divesting from fossil fuel holdings.

Source: Author's calculations based on Fridays for Future, 2021 and 350.org, 2021.

\section{Figure 2}

Greta Thunberg, "Green New Deal," and "Green Deal” Searches in Poland: May 10, 2020 - May 2, 2021

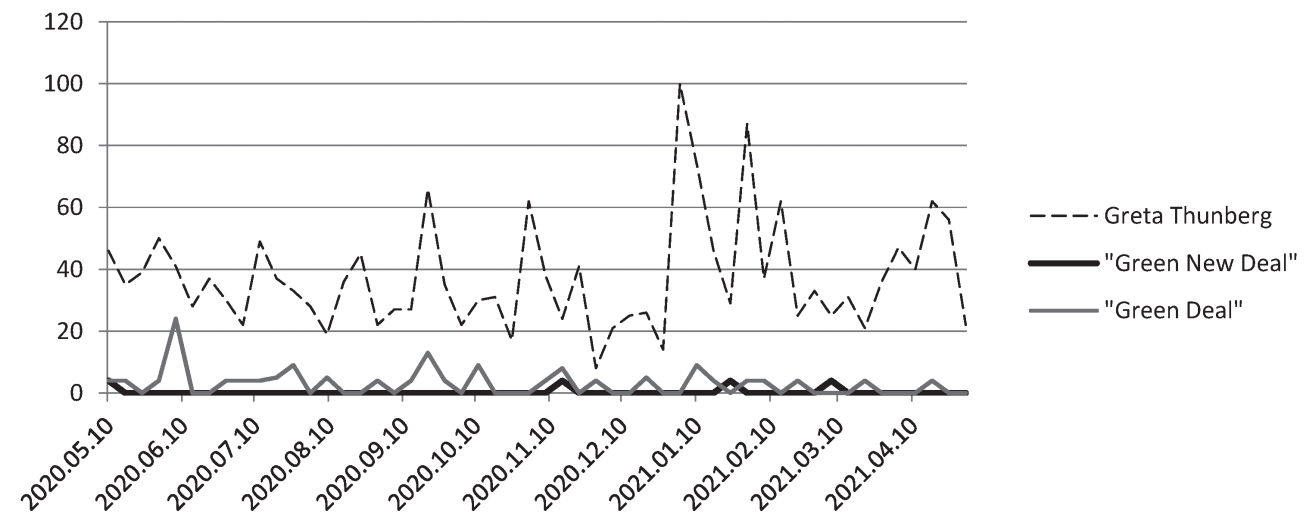

Source: Google Trends, 2021. 


\section{Figure 3}

Greta Thunberg, "Green New Deal," and "Green Deal” Searches in Germany: May 10, 2020 - May 2, 2021

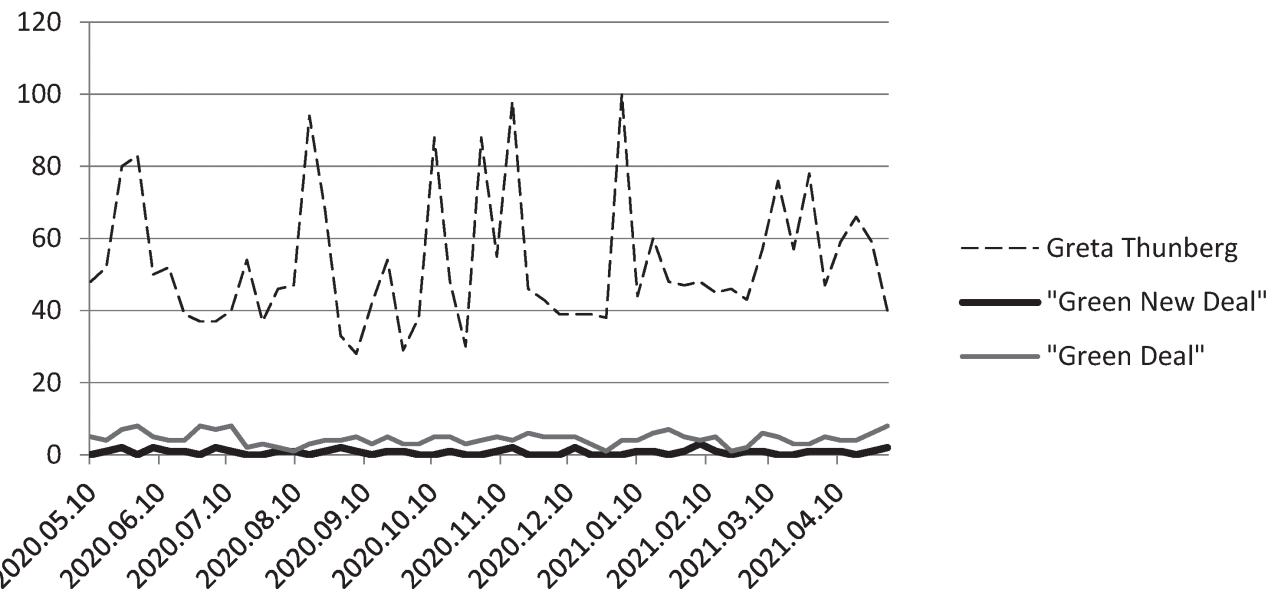

Source: Google Trends, 2021.

Figure 4

Greta Thunberg, "Green New Deal," and "Green Deal” Searches in Sweden: May 10, 2020 - May 2, 2021

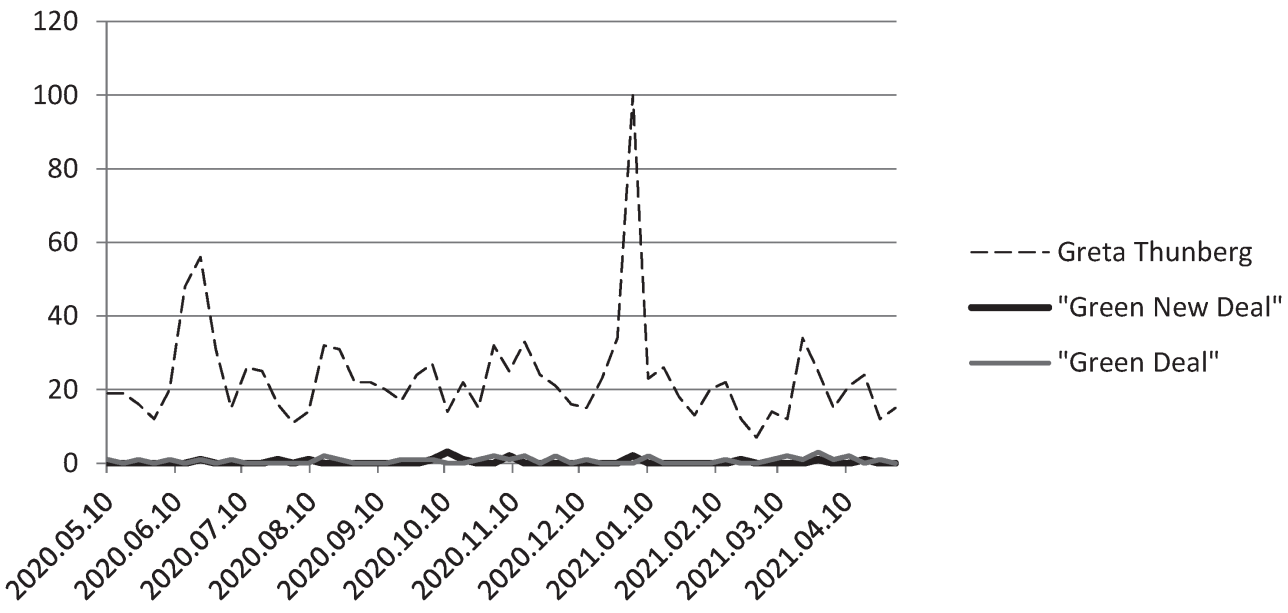

Source: Google Trends, 2021. 


\section{Figure 5}

Greta Thunberg, "Green New Deal," and "Green Deal” Searches in Bulgaria: May 10, 2020 - May 2, 2021

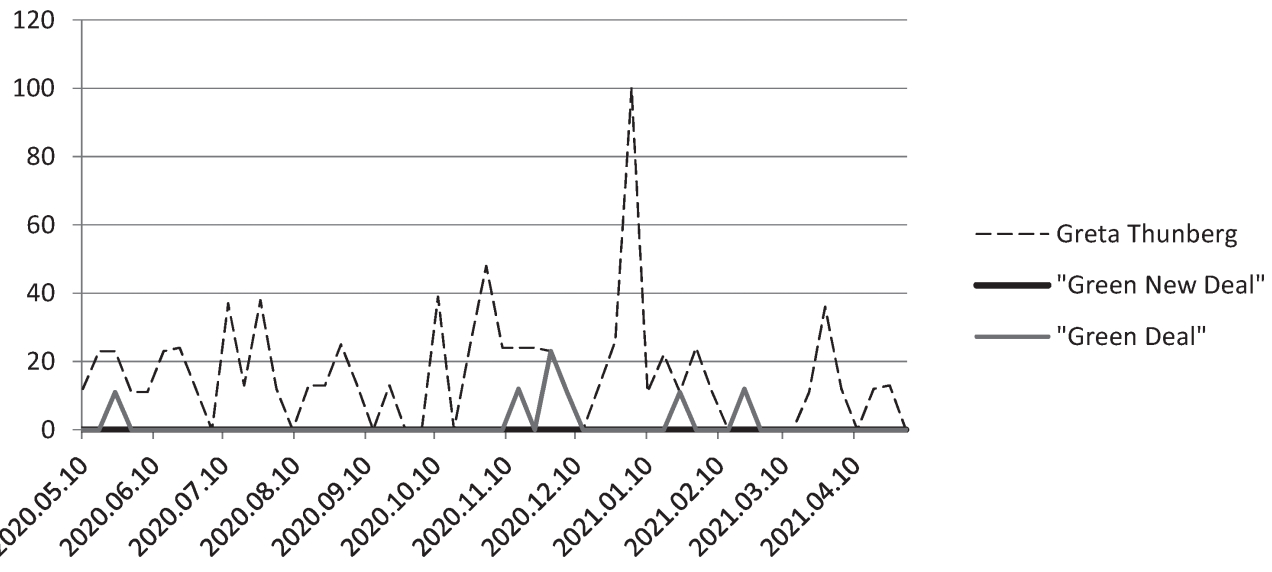

Source: Google Trends, 2021.

\section{Figure 6}

Greta Thunberg, "Green New Deal," and "Green Deal” Searches in Romania: May 10, 2020 - May 2, 2021

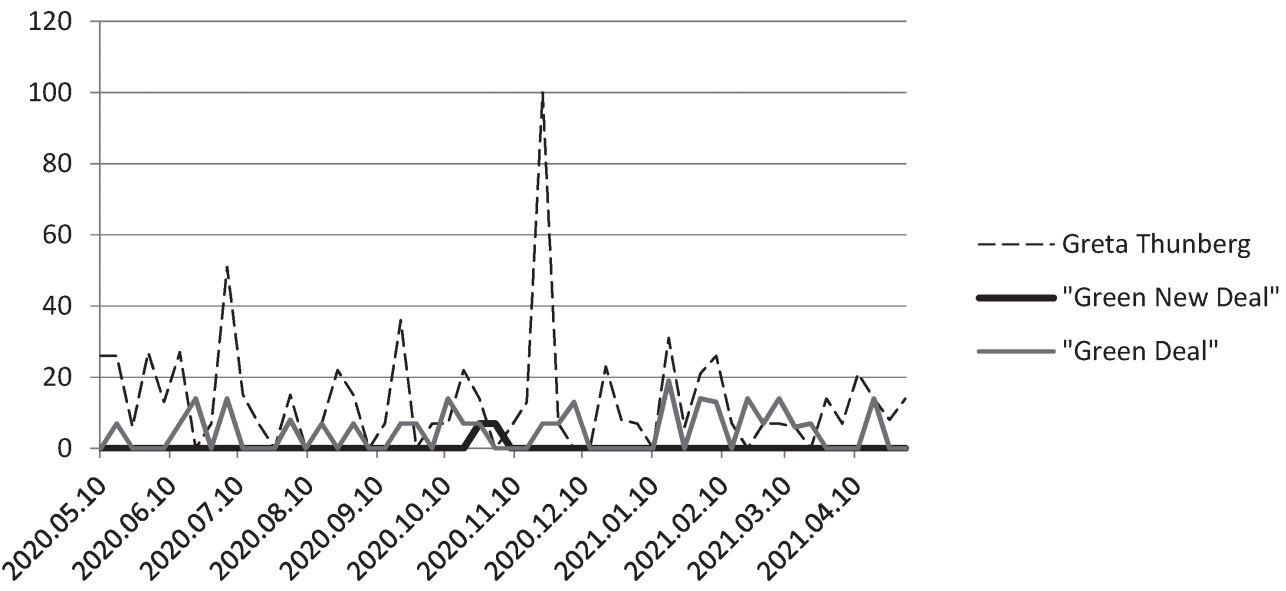

Source: Google Trends, 2021.

\section{Consciousness Raising and Facilitating Engagement}

Phase I of university reconstruction can begin with consciousness raising engagement. One can begin by analyzing alternative design criteria for the means of production (Melman, 1981). Universities can cultivate "free spaces," i.e., "settings between private lives and large-scale institutions where ordinary citizens can act with dignity, indepen- 
dence and vision." Supported by ancillary organizations or networks, the university can become a space for social change. Participants "experience a schooling in citizenship and learn a vision of the common good in the course of struggling for change" (Evans \& Boyte, 1986, pp. 17-18). Universities contain spaces for face-to-face deliberation which facilitate meetings, build associational ties, create capacities to identify opportunities, help recruit leaders as well as participants, develop frames for analyzing problems and other tasks required for mobilizations (Haug, 2013, p. 707). Colleges and universities can take the form of face-to-face "self-governing communities" which potentially distinguishes them from other spaces of work and consumption. Colleges can take the form of communities that are like "small cities, for they have a heterogeneous population and are cut off from their environments as if walled" (Goodman, 1964, p. 162, 167168). Political education and mobilization is one way to extend capacities for social change and entrepreneurship, especially important in regions that have lacked in resources; skills development is insufficient (Forcher-Mayr \& Mahlknecht, 2020).

Consciousness raising can begin by analyzing local manifestations of the problems identified in Table 1 and matching solutions to proactive possibilities in local actions related to procurement, conversion, incubators and innovation networks as well as regional, national or supra-national (e.g., EU) policy frameworks or development. This phase would involve a general understanding of the emissions contributions of universities in their distinct functions related to lecturing, student housing, research and development, administration, sports, libraries and catering, etc. (cf. Bonnet et al., 2002, p. 20).

A key barrier to consciousness raising concerns the relationship between immediate problems and underlying causal mechanisms and solutions. One needs an understanding of "a theory of society, history, and the structural processes which link them, and a theory of social forces which can serve as protagonists of change in society." Political awareness involves "a different vision of life and the world." Past student movements have promoted democratic participation as both a means to produce social change and as a goal in and of itself (Teodori, 1969, p. 49). This raises the possibility that social engagement, and experiences more generally, can be educative. Yet, "any experience is mis-educative that has the effect of arresting or distorting the growth of further experience." Apathy may result when engagement meets a lack of "responsiveness" (Dewey, 2015, pp. 25-26). Thus, one cause of student and citizen apathy can be "the unconscious recognition students make of the fact that they are powerless" (Davidson, 1969, p. 328). Yet, powerlessness itself can be derivative of many factors including lack of knowledge of how to build advocacy coalitions (which break down isolation and leverage power for change) or how to change incumbent actors through conversion processes (which reduce resistance to change by leveraging incumbents' capacities) (cf. Feldman, 1989; Sabatier, 1998; Thelen, 2003). In sum, consciousness can be blocked by barriers to engagement and engagement can be blocked by barriers to consciousness.

\section{Mapping Existing Projects and Local Capacities}

One rationale for the local mapping of university/regional green capacities is the gap "between universalized science focused on the production of global facts and local meaning-making contexts in which such facts must be interpreted and acted upon." Co-production often has locally embedded aspects because of linkages between experts, designers, innovators on the one hand and users on the other. These aspects take the 
form of regional resources that are place-specific and involve contextual knowledge that can be codified and tacit (van Kerkhoff \& Lebel, 2015, p. 2). While attention to the global scale is important, the "drive for global rules" can undermine "attention to the local knowledge" that is "necessary for implementing... global rules effectively in particular contexts" (Clark et al., 2016, p. 4571).

The so-called ICAP perspective based on innovation systems, complex systems, adaptive systems and political systems, provides implicit criteria for the scope of mapping relevant exercises. Starting with innovation, researchers' outputs become valuable for sustainability "through integration within larger innovation systems," in which these systems encompass: (a) potential users who can act on their discoveries; (b) research that is integrated with "complementary innovation processes involving adjustment to fit local contexts, field testing, scale-up, and retirement"; and (c) making knowledge usable by integrating it within "the system of existing ideas, technologies, and governing institutions" (Clark et al., 2016, p. 4571). In other words, the local university context can become a bridge between innovators and users (cf. Feldman, 2001).

\section{Creating or Deepening Networks and Strategic Interventions}

Depending upon the context, networks may already exist to implement various aspects of a university-related sustainability plan. The network form is appropriate to the realities of "co-productive capacities" which are "the combination of scientific resources and governance capacity" shaping "the extent to which a society, at various levels, can operationalize relationships between scientific and public, private, and civil society institutions and actors to effect scientifically-informed social change" (van Kerkhoff \& Lebel, 2015, p. 1).

I define "strategic interventions" as educational and organizing projects linked to a theoretical understanding and diagnosis of problems (learning), involving diverse constituencies to address climate and ecological problems. Strategic interventions partially build on ideas of urban governance. Urban governments which "in their strategies for the construction and consolidation of political territories... tend to promote settings or opportunities for collective action of an interactive, negotiated type." Consultations and contracts can "move away from situations that block decision-making" and present "possibilities for generating choices that will be more efficient because they have been made jointly" (Bobbio, 2000; as cited in Pinson, 2002, p. 480). The strategic intervention links deliberative processes like study circles to organizing campaigns involving community mobilization (Rusch \& Swarts, 2015). The strategic intervention can play several key roles.

First, they can provide a basis for learning through (a) "the accumulation of policy experience over time" and (b) "focusing events," i.e., "incidents that focus public and political attention on a policy issue." These two forms of learning can occur "in policy domains where individuals are pursuing common goals" (Busenberg, 2001, p. 174). A relationship emerges between learning and the governance system, where "policy entrepreneurs can match policy solutions to policy problems" and coalitions can link diverse groups (Wilson, 2000, p. 248).

Second, organizing on specific topics can be used to leverage depth and breadth. Jeff Shero, an activist in the U.S. Students for a Democratic Society organization, explained the process underway in the Fall of 1966: 
Organizers always understood how issues were related, and as soon as they got students in motion on one issue, as soon as they came in conflict with the authorities in the society, people would begin seeing the relationship to other issues, and the organizers could accelerate that process by explaining it.

The issues first pursued would differ by region but could be leveraged by a common network (Sale, 1974, p. 298).

Third, they can provide a bridge to overcome divisions between university and larger community:

The university is best at producing abstract, highly focused, rigorous and internally consistent forms of knowledge, while the city is more likely to produce descriptive, concrete, but also less tightly focused and more immediately useful knowledge, whether this is generated by businessmen, journalists, or professional practitioners (Bender, 2002, p. 151).

While the university and the city can "complement each other... partnering is difficult for universities." A precedent for linking the practicality of the city with the knowledge and science of the university can be found in "urban-style milieus that pose either an alternative to the university or a complementary partner," e.g., incubators and industrial campuses. These two worlds can be bridged with "two-way conversations between the various academic groupings on the campus and the appropriate constituencies in the metropolis." As an example, Seth Low, Columbia University's present in the 1890s "established important institutional collaborations with various learned societies, from the New York Botanical Garden and the New York Academy of Sciences, to the American Museum of Natural History and the Metropolitan Museum of Art, to Union Theological Seminary and the Jewish Theological Seminary." He forged networks with trade unions and settlement houses which helped incorporate immigrants (Bender, 2002, p. 153, 156-157). These networks can create a meso-level space between the university as a kind of isolated enclave "often... in conflict with the surrounding society" (Goodman, 1964 , p. 170) and the school which "depends far more on the atmosphere of national culture in which is immersed than it does on the pedagogical atmosphere created artificially within it" (Ortega y Gasset, 1944, pp. 48-49). In theory, different kinds of networks will bend the university towards different kinds of missions, where policy outcomes can benefit from engagement with politicians (cf. Sørensen \& Torfing, 2005).

Fourth, strategic interventions can provide a basis for actual coalition formation, as students, teachers and administrators potentially have different agendas. Each group is associated with subcultures that "are the product of different group histories associated with decision-making practices, time constraints, priorities, opportunities, threats and experiences" within each group. These groups may even struggle for power. Yet, "the greatest leverage in achieving institutional change occurs when all three subcultures or groups have a shared vision and a sense of organizational alignment in their respective actions" (Sharp, 2002, p. 137).

Finally, exchanges between "advanced" and "lagging" regions could extend training and technology transfer from the former to the latter. Universities can pool resources in consortia to advance common goals (cf. Feldman, 1989, p. 237, 239). Foreign aid can encompass support for greening engineering education to support ecological innovations. 


\section{Design Implementation and Infrastructure as Political Mobilization}

Universities can become part of networks defined by student organizations, teachers' associations, labor unions, green entrepreneurs, engineering societies and other actors who shape spaces. As an example, the creation of buildings, mass transit lines and alternative infrastructure not only meet ecological needs, but also potentially create a political space that helps sustain organizing campaigns. The Belgian architect Lucien Kroll (whose best-known work was a student residence) requires "that his commissions... allow the designers to work directly with the present and/or future users," so "the users themselves are as engaged as possible in the design process" (Milgrom, 2008, p. 265, 272-273). Material mobilization producing green mass transit, alternative energy and other such projects can build political capital. Paul Pierson argues "that large-scale public welfare programs are subject to important feedback effects, as they create new constituencies and beneficiaries that develop vested interests in their maintenance" (Streeck \& Thelen, 2005, p. 6).

\section{Reflective Learning and Feedback}

This stage shows how the political networks developed to address problems can become organizers of reflection and can improve plans to meet needs. A key problem in green infrastructure can involve mismatches between users' needs or preferences and the way products or services are consciously designed and implemented. Transportation examples can include deficits in on-campus public transit services, poorly designed routes, overcrowded transit vehicles, or limits in connectivity among transportation modes. Accessibility could be improved after reflecting on design failures and promoting alternative designs through planning support systems (cf. Brömmelstroet \& Schrijnen, 2010). "Double loop learning" can be used to improve the design of infrastructure (Synnott, 2013).

\section{Conclusions}

This paper outlines three problems. First, universities potentially contribute to the climate problems identified in Table 1, even as they could potentially leverage conversion processes and alternative planning to address such problems with support from external movements like FFF.

Second, divestment actions and FFF protests encompass a global network which has breadth as seen in Tables 3 and 4 , but these protests can be decoupled from a discourse related to green conversion (as suggested by Figures 2-6). The discussion above explains a five-phase approach to discursive mobilization encompassing material mobilization. This approach illustrates how activists could become engaged in addressing the problem areas identified in Table 1 and promote the institutional diversification associated with coalition building. One key goal is to link students, faculty and administrators to external actors like local farmers, green entrepreneurs, engineering associations and others to leverage university and - by extension - local (if not national) procurement to initiate ecological solutions related to food, energy, transport and other areas.

Finally, uneven development explains how some regions are more active than others. The data reveal strong clusters of more proactive states, but also many states that lag in 
relative environmental action. The paper suggests transnational procurement cooperation or engineering exchanges could involve solidaristic support between "advanced" regions to extend their resources to assist "lagging" regions. Deeper green conversion in advanced states could provide a foundation for such solidaristic, multilateral exchanges.

\section{References}

AASHE. (2015). Sustainable Campus Index, 2015. Philadelphia, The Association for the Advancement of Sustainability in Education, October. https:/www.aashe.org/ wp-content/uploads/2017/10/aashe_2015_sustainable_campus_index.pdf

Bender, T. (2002). The unfinished city: New York and the Metropolitan idea. New York: The New Press.

Bobbio, L. (1990). Archeologia industriale e terziario avanzato a Torino: il riutilizzo del Lingotto. In B. Dente, L. Bobbio, P. Fareri, \& M. Morisi (Eds.), Metropoli per progetti: attori e processi di trasformazione urbana a Firenze, Torino, Milano [Metropolis for projects: Actors and processes of urban transformation in Florence, Turin, Milan] (pp. 101-161). Bologna: Il Mulino.

Bonnet, J. F., Devel, C., Faucher, P., \& Roturier, J. (2002). Analysis of electricity and water end-uses in university campuses: Case-study of the University of Bordeaux in the framework of the Ecocampus European collaboration. Journal of Cleaner Production, 10,13-24. https://doi.org/10.1016/S0959-6526(01)00018-X

Busenberg, G. J. (2001). Learning in organizations and public policy. Journal of Public Policy, 21(2), 173-189. https://doi.org/10.1017/S0143814X0100109X

Brömmelstroet, M. T., \& Schrijnen, P. M. (2010). From planning support systems to mediated planning support: A structured dialogue to overcome the implementation gap. Environment and Planning B: Planning and Design, 37(1), 3-20. https://doi.org/ 10.1068/b35019

Clark, W. C., van Kerkhoff, L., Lebel, L., \& Gallopin G. C. (2016). Crafting usable knowledge for sustainable development. PNAS, 113(7), 4570-4578. https://doi.org/ 10.1073/pnas.1601266113

Czarnezki, J. J. (2019). Green public procurement legal instruments for promoting environmental interests in the United States and European Union. PhD Dissertation. Uppsala: Uppsala University. http://dx.doi.org/10.2139/ssrn.3504676

Davidson, C. (1969). Campaigning on campus. In A. Cockburn \& R. Blackburn (Eds.), Student power: Problems, diagnosis, action (pp. 327-364). Baltimore, Maryland: Penguin Books.

Delina, L., \& Diesendorf, M. (2013). Is wartime mobilisation a suitable policy model for rapid national climate mitigation? Energy Policy, 58, 371-380. https://doi.org/ 10.1016/j.enpol.2013.03.036

Dewey, J. (2015). Experience and education. New York: The Free Press. Abbreviated version https://doi.org/10.1080/00131728609335764

Duderstadt, J. J. (2000). A choice of transformations for the $21^{\text {st }}$ century university. The Chronicle of Higher Education, February 4. https://www.chronicle.com/article/ a-choice-of-transformations-for-the-21st-century-university/

Egan, P. J., \& Mullin, M. (2017). Climate change: US public opinion. Annual Review of Political Science, 20, 209-227. https://doi.org/10.1146/annurev-polisci-051215022857 
Elzinga, A. (1998). Theoretical perspectives: Culture as a resource for technological change. In M. Hård \& A. Jamison (Eds.), The intellectual appropriation of technology: Discourses on modernity, 1900-1939 (pp. 17-31). Cambridge, MA: MIT Press.

Environmental Performance Index. (2021). New Haven: Yale Center for Environmental Law \& Policy, Yale University. https:/epi.yale.edu/epi-results/2020/component/epi

European Commission. (2019). The European green deal. Brussels, December 11. https://eur-lex.europa.eu/legal-content/EN/TXT/PDF/?uri=CELEX:52019DC $0640 \&$ from $=\mathrm{EN}$

Eurostat. (2019). Tertiary education statistics. Brussels: European Union, November. https://ec.europa.eu/eurostat/statistics-explained/index.php/Tertiary_education_ statistics\#: :text=Planned\%20article\%20update\%3A\%20November\%202020.\& text=In $\% 20$ the $\% 20$ EU\%2D28\%20there,following $\% 20$ doctoral $\% 20$ studies $\% 20$ were $\% 20$ men

Eurostat. (2020). Share of EU greenhouse gas emission by source, 2017. Shedding length on energy in the EU. Brussels: European Union. https://ec.europa.eu/eurostat/cache/ infographs/energy/bloc-4a.html

Eurostat. (2021a). Number of tertiary education students by sex and level of education, 2018 (thousands). Brussels, Belgium. https://ec.europa.eu/eurostat/statisticsexplained/index.php/Tertiary_education_statistics\#Participation_of_men_and_ women_in_tertiary_education

Eurostat. (2021b). Students enrolled in tertiary education by education level, programme orientation, sex, type of institution and intensity of participation. Brussels, Belgium: March 19. https://appsso.eurostat.ec.europa.eu/nui/show.do?dataset=educ_uoe_ enrt01\&lang=en

Evans, S. M., \& Boyte, H. C. (1986). Free spaces: The sources of democratic change in America. New York: Harper and Row Publishers.

Feldman, J. (1989). Economic conversion: An alternative to military dependency in the University. Annals of the New York Academy of Sciences, 577(1), 231-241. https://doi.org/10.1111/j.1749-6632.1989.tb15069.x

Feldman, J. M. (2001). Towards the post-university: Centers of higher learning and creative spaces as economic development and social change agents. Economic and Industrial Democracy, 22(1), 99-142. https://doi.org/10.1177/0143831X01221005

Forcher-Mayr, M., \& Mahlknecht, S. (2020). Critical entrepreneurship education in general education and TVET: Two concepts of practice in a South African township. Discourse and Communication for Sustainable Education, 11(2), 65-84. doi: 10.2478/dcse-2020-0019

Fridays for Future. (2021). List of countries. Stockholm, Sweden. https://fridaysforfuture. org/what-we-do/strike-statistics/list-of-countries/

Friedman, J. (2016). Universities where the most students bring cars to campus. U.S. News and World Report. https://www.usnews.com/education/best-colleges/the-short-listcollege/articles/2016-10-11/universities-where-the-most-students-bring-cars-to-campus

Goodman, P. (1964). Compulsory mis-education and the community of scholars. New York: Vintage Books.

Google Trends. (2021). Author's search of Google Trends data, May 8.

Haug, C. (2013). Organizing spaces: Meeting arenas as a social movement infrastructure between organization, network, and institution. Organizational Studies, 34(5-6), 705-732. https://doi.org/10.1177\%2F0170840613479232 
Hultgren, E. (2020). Business area manager. Högskolerestauranger, Stockholm, Sweden. Communication with Jonathan Michael Feldman, October 20, 2020.

Jain, S., Aggarwal, P., Sharma, N., \& Sharma, P. (2013). Fostering sustainability through education, research and practice: A case study of TERI University. Journal of Cleaner Production, 61, 20-24. https://doi.org/10.1016/j.jclepro.2013.04.021

Jung, J., Petkanic, P., Nan, D., \& Kim, J. H. (2020). When a girl awakened the world: A user and social message analysis of Greta Thunberg. Sustainability, 12(7), 2707. https://doi.org/10.3390/su12072707

Kowarski, I. (2020). 10 Universities with the biggest endowments. U.S. News and World Report, September 22. https:/www.usnews.com/education/best-colleges/the-shortlist-college/articles/10-universities-with-the-biggest-endowments

Lambrechts, W., \& Van Liedekerke, L. (2014). Using ecological footprint analysis in higher education: Campus operations, policy development and educational purposes. Ecological Indicators, 45, 402-406. https://doi.org/10.1016/j.ecolind.2014.04.043

Linder, J. (2018). Entrepreneurship education for a sustainable future. Discourse and Communication for Sustainable Education, 9(1), 115-127. doi: 10.2478/dcse-20180009

Melman, S. (1981) Alternative criteria for the design of means of production. Theory and Society, 10(3), 325-336. https://doi.org/10.1007/BF00179267

Milgrom, R. (2008). Lucien Kroll: Design, difference, everyday life. In K. Goonwardena, S. Kipfer, R. Milgrom, \& C. Schmid (Eds.), Space, difference, everyday life: Reading Henri Lefebvre (pp. 264-281). New York: Routledge. https://doi.org/10.4324/ 9780203933213

Mohammadalizadehkorde, M., \& Weaver, R. (2018). Universities as models of sustainable energy-consuming communities? Review of Selected Literature. Sustainability, 10(9), 3250. https://doi.org/10.3390/su10093250

Morris, D. (2018). Students who commute to university are getting a raw deal. The Guardian, December 13. https://www.theguardian.com/education/2018/dec/13/ students-who-commute-to-university-are-getting-a-raw-deal

Murillo-Vargas, G., Gonzalez-Campo, C. H., \& Brath, D. I. (2021). Mapping the integration of the sustainable development goals in universities: Is it a field of study? Journal of Teacher Education for Sustainability, 22(2), 7-25. https://doi.org/ 10.2478/jtes-2020-0013

Orlowski, M. (2012). New focus at sustainable endowments institute: Billion-dollar green challenge prioritized over Green Report Card. Sustainable Endowments Institute, Cambridge, Massachusetts, March 30. http://greenreportcard.org/media.html

Ortega y Gasset, J. (1944). Mission of the university. Princeton: Princeton University Press.

Pacheco-Blanco, B., \& Bastante-Ceca, M. J. (2016). Green public procurement as an initiative for sustainable consumption. An exploratory study of Spanish public universities. Journal of Cleaner Production, 133, 648-656. https://doi.org/10.1016/ j.jclepro.2016.05.056

Pinson, G. (2002). Political government and governance: Strategic planning and the reshaping of political capacity in Turin. International Journal of Urban and Regional Research, 26(3), 477-493. https://doi.org/10.1111/1468-2427.00394

Planet Aid. (2015). Curbing the college waste problem. May 11. https://www.planetaid. org/blog/curbing-the-college-waste-problem 
Rusch, L., \& Swarts, H. (2015). Practices of engagement: Comparing and integrating deliberation and organizing. Journal of Community Practice, 23(1), 5-26. https://doi.org/10.1080/10705422.2014.985411

Sabatier, P. A. (1998). The advocacy coalition framework: revisions and relevance for Europe. Journal of European Public Policy, 5(1), 98-130. https://doi.org/10.1080/ 13501768880000051

Sabherwal, A., Ballew, M. T., van der Linden, S., Gustafson, A., Goldberg, M. H., Maibach, E. W., Kotcher, J. E., Swim, J. K., Rosenthal, S. A., \& Leiserorwitz, A. (2021). The Greta Thunberg effect: Familiarity with Greta Thunberg predicts intentions to engage in climate activism in the United States. Journal of Applied Social Psychology, 00,1-13. https://doi.org/10.1111/jasp.12737

Sale, K. (1974). SDS (Students for a Democratic Society). New York: Vintage Books. Salite, I., Fjodorova, I., Iliško, Dz., Ivanova, O., \& Meihami, H. (2020). JTES for Sustainable Development: An action research environment for the development and sustainable future of the journal identity. Journal of Teacher Education for Sustainability, 22(1), 1-5. doi: 10.2478/jtes-2020-0001

Sharp, L. (2002). Green campuses: The road from little victories to systemic transformation. International Journal of Sustainability in Higher Education, 3(2), 128145. https://doi.org/10.1177/0973408213495614c

Smith, D. A. (1994) Uneven development and the environment: Toward a world-system perspective. Humboldt Journal of Social Relations, 20(1), 151-175.

Soule, S. A. (1997). The student divestment movement in the United States and tactical diffusion: The Shanty town protest. Social Forces, 75(3), 855-883. https://doi.org/ $10.2307 / 2580522$

Stafford, S. L. (2011). How green is your campus? An analysis of the factors that drive universities to embrace sustainability. Contemporary Economic Policy, 29(3), 337356. https://doi.org/10.1111/j.1465-7287.2010.00231.x

Statista. (2020). Ranking of university catering in Germany from 2016 to 2018, by revenue. New York: Statista.com. https://www.statista.com/statistics/572019/ university-catering-by-revenue-germany/

Statista. (2021). College enrollment in the United States from 1965 to 2018 and projections up to 2029 for public and private colleges (in millions). New York: Statista.com. https://www.statista.com/statistics/183995/us-college-enrollment-and-projectionsin-public-and-private-institutions/

Streeck, W., \& Thelen, K. (2005). Introduction: Institutional change in advanced political economies. In W. Streeck \& K. Thelen (Eds.), Beyond continuity: Institutional change in advanced political economies (pp. 1-39). Oxford: Oxford University Press.

Synnott, M. (2013). Reflection and double loop learning: The case of HS2. Teaching Public Administration, 31(1), 124-134. https://doi.org/10.1177\%2F0144739413479950

Sørensen, E., \& Torfing, J. (2005). The democratic anchorage of governance networks. Scandinavian Political Studies, 28(3), 195-218. https://doi.org/10.1111/j.14679477.2005.00129.x

Teodori, M. (1969). The new left: A documentary history. Indianapolis and New York: The Bobbs-Merrill Company.

Thelen, K. (2003). How institutions evolve: Insights from comparative historical analysis. In J. Mahoney \& D. Rueschemeyer (Eds.), Comparative historical analysis in the social sciences (pp. 208-240). Cambridge: Cambridge University Press. https://doi.org/10.1017/CBO9780511803963.007 
Theunissen, M. (2019). New census data reveals more than half of NZ's students use private vehicles to commute. Stuff, October 3. https://www.stuff.co.nz/national/ education/116286172/new-census-data-reveals-more-than-half-of-nzs-students-useprivate-vehicles-to-commute

Timasheff, N. S. (1959). Order, causality, conjuncture. In L. Gross (Ed.), Symposium on sociological theory (pp. 145-164). Evanston, Illinois and White Plains, New York: Row, Peterson and Company.

Tilly, C. (1993-1994). Social movements as historically specific clusters of political performances. Berkeley Journal of Sociology, 38, 1-30.

350.org. (2021). Fossil free: Divestment. Boston, Massachusetts. https:/gofossilfree.org/ divestment/commitments/

Universities Australia. (2020). Data Snapshot, 2020. February 12. https://www.universities australia.edu.au/publication/snapshot-2020/

Universities Canada. (2021). Facts and stats. Ottawa, Ontario, Canada. https://www. univcan.ca/universities/facts-and-stats/

UW Integrated Design Lab. (2017). Campus illumination. University of Washington, Seattle, Washington, June. https://www.lightingdesignlab.com/sites/default/files/pdf/ Campus-Illumination-Roadmap-final.pdf

Van Kerkhoff, L. E., \& Lebel, L. (2015). Co-productive capacities: Rethinking sciencegovernance relations in a diverse world. Ecology and Society, 20(1), 1-6. http://dx.doi.org/10.5751/ES-07188-200114

Velazquez, L., Munguia, N., \& Sanchez, M. (2005). Deterring sustainability in higher education institutions: An appraisal of the factors which influence sustainability in higher education institutions. International Journal of Sustainability in Higher Education, 6(4), 383-391. https://doi.org/10.1108/14676370510623865

Voorhes, M. (1999). The US divestment movement. In N. C. Crawford \& A. Klotz (Eds.), How sanctions work (pp. 129-144). Basingstoke: Macmillan. https://doi.org/ 10.1057/9781403915917_6

Wang, Y., Shi, H., Sun, M., Huisingh, D., Hansson, L., \& Wang, R. (2013). Moving towards an ecologically sound society? Starting from green universities and environmental higher education. Journal of Cleaner Production, 61, 1-5. https://doi.org/ 10.1016/j.jclepro.2013.09.038

Wilson, C. A. (2000). Policy regimes and policy change. Journal of Public Policy, 20(3), 247-274. https://doi.org/10.1017/S0143814X00000842

World Bank. (2021). GDP per capital (current US\$). World Bank, Washington, D.C. https://data.worldbank.org/indicator/NY.GDP.PCAP.CD?name_desc=false

Zhao, H., \& Magoulès, F. (2012). A review on the prediction of building energy consumption. Renewable and Sustainable Energy Reviews, 16(6), 3586-3592. https://doi.org/10.1016/j.rser.2012.02.049

Correspondence concerning this paper should be addressed to Jonathan Michael Feldman, Department of Economic History and International Relations, Stockholm University, S-10691 Stockholm, Sweden. Email: jonathan.feldman@ekohist.su.se 